\title{
The Nutritional Value of some Desert plants in Kuwait, Arabian Pennisula
}

\author{
Hassan El-Tantawy \\ Department of Botany, Faculty of Science, Menufiya University.
}

El-Tantawy H. 2002. The Nutritional Value of some Desert plants in Kuwait, Arabian Pennisula. Taeckholmia 22(1):35-45.

The nutritional role of five desert plants in the diet of the inhabitants of Kuwait was investigated. Different organs of the five species (leaves, stems or the whole plants) were analyzed for mineral ion composition, amino acids, carbohydrates content, crude fat, crude fibres and crude protein: Rumex vesicarius, Malva parviflora, Suaeda aegyptiaca, Sonchus oleraceus and Cynomorium coccineum. The hydrolyzate of Sonchus oleraceus was found to contain 17 amino acids and thus representing the most valuable species, also it contains large amount of crude fibres. All five plants contained eight essential amino acids. The parasitic species (Cynomorium coccineum) contained the highest content of protein $(28.67 \%$ dry weight) and large amounts of crude fat. High concentrations of Na were recorded in Suaeda aegyptiaca (105.4mg / g oven dry weight). The levels of trace minerals detected constitute no hazardous effect on human health. Results indicated that edible desert plants of Kuwait could contribute useful amounts of essential nutrients especially in poor countries.

Key wards: Gynomorium, Malva, Nutritional value, Rumex, Sonchus, Suaeda.

\section{Introduction}

Protein malnutrition is considered one of the most serious problems in undeveloped countries. Until food technology develops to solve this problem, proteins from many botanical sources (aquatic or terrestrial plants) could be made palatable to humanbeings by selecting certain plants, which possess high protein content, crude fat, crude protein, crude fibres and mineral ions. Several investigators have suggested the utilization of aquatic plants, weeds and desert plants as additional food sources. Abo-bakr et al. (1984), stated that the leaf protein of an isolate of Eichhornia crassipes contained a high percentage of proteins together with high levels of all the essential amino acids, with the exception of methionine and cystine, which were present in limited amounts. Becker (1986), reported that wild plants can theoretically supply only about $10 \%$ of the populations by energy needs. Their contribution to the concentration to the vitamins and mineral supply is considerable, vitamins $\mathrm{A}, \mathrm{B}_{2}$ and $\mathrm{C}$.

In Kuwait, tribal people living in Kuwait are consuming several wild plants. Some wild plants are cooked, or eaten raw directly or eaten as salad. However, very little attention has been paid to the edible desert plants which are consumed by many tribal sects. Moreover, the available information regarding their nutritional evaluation is very scanty.

In the present investigation, attempts were done to investigate the protein value (amino acids) crude protein, crude fat, crude fibres and mineral composition of five edible desert plants.

\section{Materials And Methods}

The species investigated are usually collected and eaten directly as many vegetables or cooked like spinach and radish. They grow in the desert of Kuwait during or after the rainy season. The following species were the subject of the present study:

1. Rumex vesicarius L, (Fam. Polygonaceae) common desert annual which inhabits sandy soil, wadi beds and cliffs along the sea (Gulf) shores, and on 
sand dunes. The leaves are eaten raw or after being cooked, and have been used in medicine as a laxative. The local name of the species is "Hommad or Hommeid."

2. Malva parviflora L. (Fam. Malvaceae) common weed which inhabits course sandy soil, roadsides and waste places. In many countries, it is cultivated and sold as vegetable. The edible part is the blade of the leaves, which are separated and cooked as spinach. The local name of the species is "Khobbas."

3. Sonchus Oleraceus L. (Fam Compositae), weed in orchards, fields, moist ground and in sandy deserts. The edible part is the shoot system (leaves and steam) which eaten directly like radish. Its local name in celery is "Go'died, Hodeid, and Hawwa."

4. Suaeda aegyptiaca (Hasseql.) Zohary (Fam. Chenopodiaceae). It is an annual herb, 20-25 cm long, glabrous, green, very fleshy and juicy. The species inhabits saline soils and marshes. After the rainy season (from December to February) seedlings are left to grow for about a month, then they are collected and sold in markets under the local name "Gollman". It is eaten raw or added to salad for providing a salty taste.

5. Cynomorium occineum L. (Fam. Cynomoriaceae). It is a blackish-red fleshy parasitic plant, inhabiting salty maritime sandy plains. It has been observed growing frequently together with Limoniastrum monopetalum and Limonium delicatulum; which are believed to be among its host plants (Täckholm, 1974). It infects desert plants including Zygophyllum coccineum and Haloxylon salicornicum. It has a sweet taste and is appreciated by children and many adult people. Also, it has a delicious taste when grilled on firebrands. The dried powdered plant is usually used for biliary obstruction when mixed with butter. The powder could be added to meat dishes as a condiment, the vernacular name of the species is "Tarthos".

Species were identified after Migahid (1978), Daoud \& El-Rawi (1985) and Boulos (1988).

\section{Collection of samples}

The plants were collected from different sites in the desert and local markets of Kuwait. The plants were then cleaned and washed many times with tap and distilled water. The edible parts of each plant species were separated, cleaned and washed again with distilled water. Some of the cleaned and washed edible parts were dried in open air till obtaining a constant weight. The residual parts were dried in an electric oven at $90^{\circ} \mathrm{C}$ for 48 hours or up to a constant weight. After drying, the edible parts were ground and stored in a dessicator at room temperature for analysis.

\section{Proximate composition}

The moisture content was determined by the method of Jackson (1967) and the pH of the juice of edible parts was determined using a $\mathrm{pH}$ meter. Total nitrogenous compounds were 
estimated by the microkjeldahl method as described by Peach and Tracey (1956) and the crude protein content was calculated ( $\mathrm{N}$ x 6.25). Crude fibres, crude fats and ash were determined according to AOAC methods (1980). Total soluble carbohydrates were also determined according to the method of Allen (1974).

\section{Mineral analysis}

All plant samples were acid-digested (hydrochloric acid and nitric acid) before the determination of $\mathrm{Na}, \mathrm{K}, \mathrm{Ca}, \mathrm{Mg}, \mathrm{Cr}, \mathrm{Co}, \mathrm{Zn}, \mathrm{Pb}$, and $\mathrm{Ni}$ concentrations using atomic absorption spectrophotometry, where AAS-Flame was used for the analysis of $\mathrm{Cr}, \mathrm{Co}, \mathrm{Cu}, \mathrm{Zn}$, $\mathrm{Fe}$ and $\mathrm{Mn}$; AAS-Graphite Furnace for $\mathrm{Pb}$ and $\mathrm{Ni}$; and ICP for $\mathrm{Na}, \mathrm{K}, \mathrm{Ca}$ and $\mathrm{Mg}$.

\section{Amino acid analysis:}

The protein of $20 \mathrm{mg}$ dry weight of each sample was extracted by $1 \mathrm{M} \mathrm{NaOH}$ at $37^{\circ} \mathrm{C}$ for 2 hours, followed by neutralization with $1 \mathrm{M} \mathrm{HCl}$. The protein was hydrolyzed by an equal value of $12 \mathrm{M} \mathrm{HCl}$ at $105^{\circ} \mathrm{C}$ for one day in Teflon screw-capped tubes. The hydrolyzate was evaporated to dryness under vacuum, extracted with ethanol, evaporated to dryness, redissolved in $0.1 \mathrm{M}$ lithium citrate buffer $(\mathrm{pH} 2)$ and analyzed with an Eppendorf amino acid analyzer (LC 3000) at the Regional Center for Mycology and Biotechnology, Al-Azhar University.

\section{Results and Discussion}

The concepts used in describing the macronutrient content of food have their origins in the socalled "proximate system" which was developed in the last century by agricultural chemists concerned with animal nutrition (Henneberg \& Stahmann, 1860,1864). In the "proximate system" the major components of food fall into four major categories; moisture (or water content), ash (the mineral content), fat and carbohydrate (Heijden et al., 1999).

The categories protein, fat and carbohydrate together with the energy or caloric content constitute the "big four" and still widely used as the basis for nutritional labeling.

\section{Amino acids content}

Table (1) shows that 12 amino acids were detected in the hydrolyzate of Rumex vesicarius, Malva parviflora and Cynomorium coccineum. The hydrolyzate of Suaeda aegyptiaca contained 13 amino acids, while that of Sonchus oleraceus was found to contain 17 amino acids and thus representing the most valuable species. Among the essential amino acids (EAA), eight were present in the five species investigated (lysine, histidine, arginine, valine, methionine, isoleucine and phenylalanine); Malva parviflora lacked valine and isoleucine. Phenylalanine content was very high in Cynomorium coccineum $(20.94 \%)$ followed by Suaeda aegyptiaca (13.45\%), Malva parviflora (13.11\%), Rumex vesicarius $(13.01 \%)$ and Sonchus oleraceus (8.2\%). Glutamic acid, proline, alanine and cysteine were recorded only in Sonchus oleraceus. In the five species investigated, aspartic acid, glycine and threonine were completely absent, while the concentration of $\gamma$-aminobutyric acid, cystathionine and phosphoserine were found to vary from traces to small quantities. No marked changes were observed for the other amino acids.

Moreover, a big difference in the total content of amino acids in the five species was observed. In Rumex vesicarius the total content was found to decrease to reach a value of $53.35 \%$ while in Sonchus the percentage was found to increase reaching a value of $92.81 \%$. 
Table 1: Amino acid content $(\mathrm{gm} / 100 \mathrm{gm})$ in the hydrolysates of the five investigated species.

\begin{tabular}{|l|c|c|c|c|c|}
\hline Species & $\begin{array}{c}\text { Rumex } \\
\text { vesicarius }\end{array}$ & $\begin{array}{c}\text { Malva } \\
\text { parviflora }\end{array}$ & $\begin{array}{c}\text { Sonchus } \\
\text { oleraraceus }\end{array}$ & $\begin{array}{c}\text { Suaeda } \\
\text { aegyptiaca }\end{array}$ & $\begin{array}{c}\text { Cynomorium } \\
\text { coccineum }\end{array}$ \\
\hline Lysine & 4.67 & 9.97 & 4.77 & 7.34 & 5.59 \\
\hline Histidine & 2.48 & 4.14 & 1.30 & 2.46 & 2.13 \\
\hline Arginine & 4.39 & 6.84 & 2.46 & 6.75 & 7.57 \\
\hline Aspartic acid & - & - & - & - & - \\
\hline Threnine & - & - & - & - & - \\
\hline Serine & 4.36 & 8.09 & 4.20 & 4.82 & 4.47 \\
\hline Phosphoserine & 1.37 & 2.20 & 1.78 & 2.18 & 1.70 \\
\hline Phosphoethanolamine & 3.13 & 3.96 & 4.26 & 2.33 & 3.65 \\
\hline Glutamic acid & - & - & 11.14 & - & - \\
\hline Proline & - & - & 9.72 & - & - \\
\hline Glycine & - & - & - & - & - \\
\hline Alanine & - & - & 5.79 & - & - \\
\hline Cysteine & - & - & 5.45 & - & - \\
\hline Valine & 5.17 & - & 5.38 & 7.00 & 4.73 \\
\hline Methionine & 4.08 & 8.44 & 4.59 & 6.36 & 3.81 \\
\hline Isoleucine & 7.05 & - & 8.41 & 10.73 & 6.29 \\
\hline Leucine & 2.56 & 4.21 & 2.00 & 2.89 & 3.69 \\
\hline Tyrosine & - & 13.32 & 6.29 & 8.56 & 4.37 \\
\hline Phenylalanine & 13.01 & 13.11 & 8.20 & 13.45 & 20.94 \\
\hline $\begin{array}{l}\text { Gamma-Amino Butyric } \\
\text { acid }\end{array}$ & 53.35 & 75.34 & 92.81 & 75.41 & - \\
\hline Cystathionine & 0.96 & 1.07 & - & - \\
\hline Total amino acids & & 0.10 & - & 0.54 & \\
\hline & & & & & -94 \\
\hline
\end{tabular}

It is worth noting that leucine, isoleucine, valine, phenylalanine and methionine are essential to maintain the nitrogen balance in mankind (Harper, 1963). Most of these amino acids were detected in the investigated species except for Malva parviflora in which valine was not detected. Cystine which is responsible for strengthening the root of human hair and its growth (Harper, 1963) was present only in Sonchus oleraceus, thus cystine is an amino acid moiety in protein synthesis rather than acting as a stimulant for hair growth.

Regarding the crude protein content (Table 2), it has been found to vary from one species to another. The parasitic Cynomorium coccineum contained the highest amount of 
crude protein (28.67\%) followed by Malva parviflora $(20.96 \%)$, Sonchus oleraceus (18.56\%) Suaeda aegyptiaca (13.24\%) and Rumex vesicarius (10.79\%).

From a nutritional point of view, no distinction should be made between animal or plant protein (Pirie,1957). The most important factor determining the biological value of a protein is the relative concentration of its amino acids, particularly of the essential ones.

Akeson and Stahman (1965), studied the amino acid content of several animal and plant proteins and suggested that neither the biological value (BV) nor the amino acid content of the leaf protein from Chenopodium, turnip, Sonfion, ryegrass, Nasturtium, clover or alfalfa was in any way inferior to that of wheat or corn.

\section{Moisture content and $\mathrm{pH}$}

The moisture content in the investigated five plant species was very high (Table 2); it ranged between $93.23 \%$ for Rumex vesicarius and $78.67 \%$ for Cynomorium coccineum. The $\mathrm{pH}$ value of juice of five plants ranged from 3.27 (Rumex vesicarius) to 8.13 (Suaeda aegyptiaca) (Table 2)

Table 2: Different types of analysis (Proximate system), on the five investigated species.

\begin{tabular}{|c|c|c|c|c|c|c|c|}
\hline $\begin{array}{l}\text { Analysis } \\
\text { Species }\end{array}$ & $\begin{array}{c}\text { Moisture } \\
\text { content } \\
(\%)\end{array}$ & $\mathrm{pH}$ & $\begin{array}{c}\text { Crude } \\
\text { protein } \\
(\%)\end{array}$ & $\begin{array}{l}\text { Crude } \\
\text { fat } \\
(\%)\end{array}$ & $\begin{array}{l}\text { Crude } \\
\text { fibres } \\
(\%)\end{array}$ & $\begin{array}{l}\text { Ash } \\
(\%)\end{array}$ & $\begin{array}{c}\text { Total soluble } \\
\text { Carsbohydrates } \\
\text { (\%) }\end{array}$ \\
\hline $\begin{array}{c}\text { Rumex } \\
\text { vesicarius }\end{array}$ & $\begin{array}{c}93.229 \\
\pm \\
0.30\end{array}$ & $\begin{array}{c}3.27 \\
\pm \\
0.11\end{array}$ & $\begin{array}{c}10.79 \\
\pm \\
0.74\end{array}$ & $\begin{array}{c}1.801 \\
\pm \\
0.46\end{array}$ & $\begin{array}{c}1.821 \\
\pm \\
0.45\end{array}$ & $\begin{array}{c}24.470 \\
\pm \\
1.9\end{array}$ & $\begin{array}{c}1.876 \\
\pm \\
0.33\end{array}$ \\
\hline $\begin{array}{c}\text { Malva } \\
\text { parviflora }\end{array}$ & $\begin{array}{c}82.003 \\
\pm \\
1.85\end{array}$ & $\begin{array}{c}6.42 \\
\pm \\
0.11\end{array}$ & $\begin{array}{c}20.964 \\
\pm \\
1.99\end{array}$ & $\begin{array}{c}0.866 \\
\pm \\
0.13\end{array}$ & $\begin{array}{c}11.080 \\
\pm \\
1.33\end{array}$ & $\begin{array}{c}13.883 \\
\pm \\
2.145\end{array}$ & $\begin{array}{c}0.933 \\
\pm \\
0.05\end{array}$ \\
\hline $\begin{array}{l}\text { Sonchus } \\
\text { oleraceus }\end{array}$ & $\begin{array}{c}86.734 \\
\pm \\
0.80\end{array}$ & $\begin{array}{c}5.67 \\
\pm \\
0.12\end{array}$ & $\begin{array}{c}18.558 \\
\pm \\
0.48\end{array}$ & $\begin{array}{c}1.477 \\
\pm \\
0.32\end{array}$ & $\begin{array}{c}28.243 \\
\pm \\
3.05\end{array}$ & $\begin{array}{c}21.43 \\
\pm \\
1.02\end{array}$ & $\begin{array}{c}1.667 \\
\pm \\
1.3\end{array}$ \\
\hline $\begin{array}{c}\text { Suaeda } \\
\text { aegyptiaca }\end{array}$ & $\begin{array}{c}93.739 \\
\pm \\
1.15\end{array}$ & $\begin{array}{c}8.13 \\
\pm \\
0.34\end{array}$ & $\begin{array}{c}13.236 \\
\pm \\
1.93\end{array}$ & $\begin{array}{c}2.219 \\
\pm \\
0.91\end{array}$ & $\begin{array}{c}4.348 \\
\pm \\
1.32\end{array}$ & $\begin{array}{c}33.34 \\
\pm \\
1.45\end{array}$ & $\begin{array}{c}2.067 \\
\pm \\
0.981\end{array}$ \\
\hline $\begin{array}{l}\text { Cynomrium } \\
\text { coccineum }\end{array}$ & $\begin{array}{c}78.667 \\
\pm \\
1.50\end{array}$ & $\begin{array}{c}5.40 \\
\pm \\
0.13\end{array}$ & $\begin{array}{c}28.671 \\
\pm \\
2.55\end{array}$ & $\begin{array}{c}9.359 \\
\pm \\
1.24\end{array}$ & $\begin{array}{c}2.163 \\
\pm \\
0.88\end{array}$ & $\begin{array}{c}14.191 \\
\pm \\
2.25\end{array}$ & $\begin{array}{c}10.933 \\
\pm \\
1.88\end{array}$ \\
\hline
\end{tabular}

The cell sap of Rumex vesicarius leaves has a $\mathrm{pH}$ of 3.2 , due to accumulation of organic acids. In this respect, it approaches the pressed sap of lemon fruits which has a $\mathrm{pH}$ of 2.5 , due to the presence of as much as $58 \mathrm{mg}$ citric acid per ml. Leaves of many plants also have this ability (accumulation of organic acids ) and members of Crassulaceae, are notable for the diurnal variation in the amount of leaf acids, mainly citric, malic and isocitric acids (Ranson,1965). 


\section{Carbohydrates content}

Carbohydrate is the most important fuel for high-intensity exercise and performance. Since the human body has limited stores of carbohydrates as glycogen in muscle and liver, it is clear that oral supplementation will definitely affect performance, especially when the endogenous carbohydrate stores are consumed, which normally occurs after 60-90 minutes of moderately intense exercise (Heijden et al., 1999).

Recent studies have shown that although the oxidative capacity of the muscle for carbohydrate coming from circulation is up to $2 \mathrm{gm} / \mathrm{min}$; the liver will not allow an increase in glucose output and hence the muscle uptake greater than $1 \mathrm{gm} / \mathrm{min}$ (Rehrer et al., 1992).

The percentage of total soluble carbohydrates percentage has been estimated to be $1.876 \pm 0.33,0.933 \pm 0.05,1.667 \pm 1.3,2.067 \pm 0.981$ and $10.933 \pm 1.88$ for Rumex vesicarius, Malva parviflora, Sonchus oleraceus, Suaeda aegyptiaca and Cynomorium coccineum respectively. Thus Cynomorium coccineum is the plant species with the highest carbohydrate content (Table 2).

\section{Fats}

Depending on age and sex, fat intake should not represent more than $25 \%$ of the available energy consisting of one third mono-unsaturated and one third poly-unsaturated fatty acids. This recommendation regarding fat intake is valid not only for individuals genetically at risk for premature ischemic heart disease, but for the whole population (Heijden et al., 1999).

Cynomorium coccineum represent the species with the highest percentage of crude fat $(9.359 \pm 1.24 \%)$ while Malva parviflora has been found to contain the lowest percentage of $0.866 \pm 0.13$ (Table 2).

\section{Crude fibres}

Dietary fibre was a term developed as "shorthand" for the plant cell wall material in the diet (Asp et al., 1992). This plant cell wall material is not digested in the human small intestine and the indigestibility of these components by the small intestine enzymes was used as the basis for developing the total dietary fibre of the AOAC (1980), which is the official method for fibre in nutritional labeling in the USA and several other countries (Lee et al., 1992).

Sonchus oleraceus (Table 2), represents the species with the maximum crude fiber content $(28.243 \pm 3.05 \%)$ followed by Malva parviflora (11.080 \pm 1.33$)$, Suaeda aegyptiaca (4.348 \pm 1.32$)$, Cynomorium coccineum (2.163 \pm 0.88$)$ and Rumex vesicarius $(1.801 \pm 0.46)$. The cell walls from tissues of edible plants, some polysaccharides food additives and dietary fiber (DF) are very important in the human colon ( Selvendran, 1984).

It is also worth noting that fibres are of value in decreasing serum cholesterol level (Anderson et al., 1990).

\section{Mineral composition}

Table (3) shows that sodium (Na) represents the main cation, accounting for about $10 \%$ of the dry weight. Suaeda aegyptiaca was found to have the highest sodium concentration which accounts for the salty taste of this species. However, Malva parviflora was observed to be of the least sodium concentration $(4.02 \mathrm{mg} / \mathrm{gm}$ oven dry weight). The potassium $(\mathrm{K})$ content in 
the five species ranged from $37.27 \mathrm{mg} / \mathrm{g}$ in Rumex vesicarius to $19.54 \mathrm{mg} / \mathrm{g}$ in Cynomorium coccineum.. Similar trend was observed regarding calcium $(\mathrm{Ca})$. On the other hand, low concentrations of magnesium $(\mathrm{Mg})$ have been detected in all species examined; ranging from $1.2 \mathrm{mg} / \mathrm{gm}$ in Malva parviflora to $3.22 \mathrm{mg} / \mathrm{gm}$ in Sonchus oleraceus.

Leaves and stems were found to accumulate high concentrations of most of the minerals than the other plant organs. The halophyte Suaeda aegyptiaca, accumulates high concentrations of sodium which act as a regulator for the osmotic potential (Yagodin, 1982., Wiebe and Walter,1972)

In this respect the magnesium $(\mathrm{Mg})$ concentration in cow's milk is approximately $130 \mathrm{mg} / \mathrm{Lt}$. The least magnesium concentration is the $1240 \mathrm{mg} / \mathrm{kg}$ in Malva parviflora while the highest concentration is $3220 \mathrm{mg} / \mathrm{kg}$ in Sonchus oleraceus (Table 3).

Table 3: Mineral ion composition ( $\mathrm{mg} / \mathrm{gm}$ oven dry weight) of the five investigated species.

\begin{tabular}{|l|c|c|c|c|}
\hline \multicolumn{1}{|c|}{ Species } & $\mathrm{Na}$ & $\mathrm{K}$ & $\mathrm{Ca}$ & $\mathrm{Mg}$ \\
\hline Rumex vesicarius & 11.672 & 37.268 & 23.080 & 3.156 \\
\hline Malva parviflora & 4.016 & 26.776 & 26.324 & 1.240 \\
\hline Sonchus oleraceus & 21.924 & 33.32 & 20.404 & 3.22 \\
\hline Suaeda aegyptiaca & 105.468 & 28.740 & 15.212 & 2.992 \\
\hline Cynomorium coccineum & 23.716 & 19.540 & 01.540 & 3.064 \\
\hline
\end{tabular}

\section{Heavy metals}

Many researches have shown that heavy metals, when deposited onto soils (sandy soils are exceptions) are quite immobile. Unless removed by physical processes, they tend to accumulate in surface soil at or near the depth at which they are incorporated (Page et al., 1995) representing contaminants of essential elements (Ahmed, 1999).

\section{Zinc}

The recommended dietary allowance (RDA) for zinc is $125 \mathrm{mg} /$ day for people aged 11 years old (NRC, 1980), but zinc available in the US food supply is only $\sim 12.3 \mathrm{mg}$ per capita (NRC,1989). The RDA for zinc is very high when compared to the zinc content of the five plant species examined. Malva parviflora represent the species with the highest $\mathrm{Zn}$ content $(90.204 \mathrm{mg} / \mathrm{g})$, while Cynomorium coccineum is the species with the lowest $\mathrm{Zn}$ content $(0.004$ $\mathrm{mg} / \mathrm{g}$ ), (Table 4).

Table 4: Heavy metal content (mg/gm oven dry weight) of the five investigated species.

\begin{tabular}{|l|c|c|c|c|c|c|c|c|}
\hline \multicolumn{1}{|c|}{ Species } & $\mathrm{Fe}$ & $\mathrm{Cu}$ & $\mathrm{Zn}$ & $\mathrm{Mn}$ & $\mathrm{Cr}$ & $\mathrm{Co}$ & $\mathrm{Pb}$ & $\mathrm{Ni}$ \\
\hline Rumex vesicarius & 0.168 & 0.012 & 0.196 & 0.060 & 0.016 & 0.028 & 0.001072 & 0.0012 \\
\hline Malva parviflora & 0.244 & 0.002 & 0.204 & 0.080 & 0.004 & 0.016 & 0.002680 & 0.0040 \\
\hline Sonchus oleraceus & 0.448 & 0.004 & 0.044 & 0.036 & 0.012 & 0.012 & 0.000048 & 0.0028 \\
\hline Suaeda aegyptiaca & 0.124 & 0.004 & 0.056 & 0.016 & 0.004 & 0.020 & 0.000960 & 0.0016 \\
\hline
\end{tabular}




\begin{tabular}{|l|l|l|l|l|l|l|l|l|}
\hline Cynomorium coccineum & 0.068 & 0.004 & 0.004 & 0.004 & 0.008 & 0.012 & 0.000760 & 0.0084 \\
\hline
\end{tabular}

\section{Iron}

Iron is an essential element present in all body cells, as a component of haemoglobin and myoglobin and as a constituent of certain oxidative enzymes such as cytochrome and xanthine oxidases (Moffat \&Whittle, 1999).

Dietary intakes for 15-years old boys and girls from two different regions in Sweden ranged from 7-35 mg/day and from 6-27 mg/day, with daily median intakes of 18.7 and 14.2 mg, respectively (Samuelson et al., 1996). Higher dietary iron intake among 299 urban preschool children in Maryland (ages 9 months to 15 years) was associated with lower lead blood levels (Hammad et al. 1996).

It is worth mentioning that the investigated plants are good sources of iron (Table 4) with Sonchus oleraceus being the richest source $(0.448 \mathrm{mg} / \mathrm{g})$.

\section{Copper}

Rumex vesicarius, having a copper content of $12 \mathrm{mg} / \mathrm{kg}$ could be cited among the food plants with the greatest natural amount of copper when compared with beef liver which contains $11 \mathrm{mg} / \mathrm{kg}$. The National Research Council (NRC) of USA has set an estimated safe and adequate dietary intake (ESADDI) level of copper at $0.5-1 \mathrm{mg} /$ day for infants; $1-2.5 \mathrm{mg} /$ day for children and 2-3 mg/day for those over 11 years old (NRC, 1980). The consumption of 250 gm of Rumex vesicarius leaves could supply the human body with the daily copper requirements.

\section{Manganese}

The NRC ESADDI level of manganese is $1-3 \mathrm{mg} /$ day for children up to 10 years old, and 2.5$5 \mathrm{mg}$ for adolescents and adults (NRC, 1980). Hence the investiged species are considered rich sources of $\mathrm{Mn}$ with Malva parviflora being the richest source $(80 \mathrm{mg} / \mathrm{kg})$. It should be noted that dietary manganese appears to be non-toxic (NRC, 1989).

\section{Lead}

Fortunately, none of the plant species investigated in this work (Table 4), have a $\mathrm{Pb}$ level exceeding that of the permissible FDA $(0.3 \mathrm{ppm})$, which reflects the safe use of these plants by human beings (Bahatia \& Choudhri, 1996).

\section{Chromium}

It has been reported that the chromium content in food is low, and most intake of chromium is from food, estimated to be less than $100 \mathrm{mg} /$ day (Moffat \& Whittle, 1999).

Low levels chromium have been detected in the five species examined which ranged between $0.016 \mathrm{mg} / \mathrm{kg}$ in Rumex vesicarius and $0.008 \mathrm{mg} / \mathrm{kg}$ in Cynomorium coccineum (Table 4). Hence no fear of using such plants as food for human consumption regarding chromium toxicity.

\section{Magnesium}


Magnesium is an essential nutrient and a co-factor for many enzymes, particularly metallcoenzymes associated with phosphate. However, high magnesium concentrations are toxic and its toxicity is similar to that of zinc (Hammond \& Beliles, 1980 and Goyer, 1995).

Trace elements are essential for leaf growth, cell wall bonding ( $\mathrm{Ca}$ and $\mathrm{Mg}$ ), chlorophyll synthesis ( $\mathrm{Fe}, \mathrm{Mg}$ and $\mathrm{Ca}$ ) vitamins and coenzymes (Fe, Co and $\mathrm{Zn}$ ) colour, smell and taste (Mn, Fe, Co, Ni, Cu, and $\mathrm{Ag}$ ) and protein $(\mathrm{Cu}$ and $\mathrm{Zn}$ ), (cf. Rashed \& Awadallah, 1998)

The magnesium ash content of dry weight of the investigated species, varied from $1.24 \mathrm{mg}$ in M. parviflora to $2.99 \mathrm{mg}$ in S. aegptiaca (Table 3). High ash content of Suaeda may be due to mild accumulation of many salts as found in many other halophytes (Wiebe \& Walter, 1972; Abd El- Rahman et al., 1975). The salty taste may be referred to accumulation of many salts in shoot system of Suaeda aegyptiaca.

\section{The Folk Midicine:}

In folk medicine, some of the studied species were used,viz., Rumex vesicarius which contains albuminoids, sugars and woody fibres. The plant is stomachic, diuretic and astringent. The juice allays toothache, checks nausea and promotes appetite. The plant is an antidote to scorpion-stings, (Mossa et al., 1987).

The seeds of Malva parviflora are used as a demulcent in coughs and ulcer in the bladder. In Europe, an infusion of the leaves is drunk as a nerve tonic. The leaves are also used as a hot poultice for wounds and swellings. In Africa, the leaf decoction is used as a remedy for tap worms and also as lotion for bruised limbs (Mossa et al., 1987). Flowering and fruiting branches are used as a gargle for their astringent properties, also bechic and emollient (Boulos and El-Hadidi, 1984). The entire plant of Cynomorium. coccineum is used as a plant aphrodisiac, spermatopoietic, tonic, astringent (Boulos, 1983).

In conclusion, the five plant species could be used as foods of good nutritional values where Cynomorium coccineum represent the species with the highest crude protein, fat and carbohydrate contents. Additionally its protein hydrolyzate contained eight essential amino acids. However, this species contain lower levels of minerals and fibres when compared to the other species investigated. Also the levels of the heavy metals detected constitute no hazardous effects on human health.

Consequently, owing to their good nutritional value, especially protein and amino acids, the five plant species investigated represent useful foods for human consumption. It might be encouraging to know that generally the health and diets of adult western vegetarian groups have been studied extensively and appear to be good, as the low content of saturated fat and the high fiber content offer advantages (Heijden et al., 1999).

\section{References}

Abd El-Rahman, A.A.; Ezzat, N.H. \& Hussein, A.H. 1975. Variations in the mineral ion composition of plant material in the different ecological groups. Flora, 164:73-84.

Abo-Bakr, T.M.; El-Shemi, M.N. and Mesallam, S.A. 1984. Isolation and chemical evaluation of protein from water hyacinth. Plant Food for Human Nutrition. 34(1): 67-74.

Ahmed, F.E. 1999. Trace metal contaminants in food in environmental contaminants in food. Scheffield Academic Press

Allen,S.E.; Grimshaw,M.H.; Parkinson, A.J. \& Quarmby,C. 1974. Chemical analysis of ecological materials. Blackwell Scientific Publications, Oxford. 
Akeson, W.R. \& Stahman, M.A., 1965. Nutritive value of leaf protein concentrate, an in vitro digestion study. J. Agric. Food Chem, 13:145-149.

Anderson, J.W. 1990. Diatery fiber and coronary heart disease. Crit. Riv. Food Sci. Nutr. 29: 95-146.

AOAC 1980. Official methods of analysis. The Association of Official Analytical Chemists, Washington, DC, USA.

Asp,N.G.; Schweizer, T.F.; Souyhgate, D.A.T. \& Theander, O. 1992. Dietary fiber analysis, Dietary fiber. A Component of Food: 57-101. Springer Verlag, Heidelberg.

Bahatia, I., \& Choudhri, G.N. 1996. Lead poisoning of milk- the basic need for the foundation of human civilization. Indian Journal of Public Health 40(1):24-26.

Becker, B. 1986. Wild Plants for Human Nutrition in the Sahelian Zone. Journal of Arid Environment 11(1): 61-64.

Boulos, L. 1983. Medicinal Plants of North Africa. R. Publication, Inc. Algonac, Michigan, 48001. 1988. The Weed Flora of Kuwait. Kuwait University Press.

\& El-Hadidi, M.N. 1984. The Weed Flora of Egypt. The American Univ. in Cairo Press, cairo Egypt.

Daoud, H.S. \& El-Rawi, A. 1985. Flora of Kuwait. Vol.1, Kuwait Univ.- KPI London, Boston and Melbourne.

Goyer, R.A. 1995. Toxic effects of metals, in Klassen,C.D.; Amdur, M.O. \& Doull, J. (eds.) Casarett and Doull's Toxicology; The Basic Science of Poisons, 691-763, McGraw Hill, New York.

Hammad,T.A.; Sexton, M. \& Longenberg, P. 1996. Relationships between blood and dietary iron intake in pre-school children. Across Sectional Study, Annals of Epidemiology, 6(1): 30-33.

Hammond, P.B. \& Beliles, R.B. 1980. Metals in Doull, J.; Klassen, C.D. and Amdur, M.O. (eds.) Csarett and Doull's Toxicology; The Basic Science of Poisons: 409-467 Macmillan, New York.

Harper, H.A. 1963. Review of physiological chemistry. Maruzen (Asian Edition).

Heijden, K.U.D.; Younes, M.; Fishbein, L. \& Miller, S. 1999. International Food Safety Hand Book. Marcel Dekker Inc.

Henneberg, W. \& Stohmann, F. 1860, 1864. Biträge zur eins rationellen fotter angewandte Kaue, I\&II. Weende Exp. Stn., Braunschweig.

Jackson, M.L. 1967. Soil Chemical Analysis. New Delhi, India.

Lee, S.C.; Prasky, L. \& Devries, J.W. 1992. Determination of total soluble and insoluble dietary fiber in foods- enzymatic- gravimetric method, MES-TRIS buffer, collaborative study. J.A.O.A.C. Int., 75: 395-416.

Migahid, A.M. 1978. Flora of Saudi Arabia, Vol.1. Riyadh Univ. Publication.

Moffat, C.F. \& Whittle, K.J. 1999. Enviromental Contaminants in Food. Sheffield Academic Press.

Mossa, J.S.; Al-Yahya, M.A. \& Al-Meshal, I.A. 1987. Medical Plants of Saudi Arabia. Vol.1, King Saud Univ. Libraries. Riyadh 11495, Saudia Arabia.

NRC (National Research Council). 1980. Recommended Dietary Allowance, (ed. 9). US National Acadamy of Science.National Academy Press, Washington, DC. USA. 1998. Diet and Health: Implications for Reducing Chronic Disease Risk. National Academy Press, Washington. DC. USA. 
Page, A.L.; Berthelin, J. \& Stotzky, G. 1995. Position paper of part 1: Transformation of toxic metals and other inorganics as influenced by soil colloids and microorganisms. Environmental impact of soil component interactions.CRC. Press. Inc., pp 117-119.

Peach, K. \& Tracey, M.V. 1956. Modern Methods of Plant Analysis. Springer Verlag, Berlin.

Pirie, N.W. 1957. Leaf protein as human food. Manual., 32: 416-419.

Ranson, S.L. 1965. In Plant Biochemistry. Bonner, J. \& Varner, ,(eds.). The plant acids. Academic Press, New York.

Rashed, S. L. 1965. The plant acids, in Bonner, J. \& Varner, M. (eds.). Plant Biochemistry: 215-230. Academic Press, New York.

Rehrer, N.J.; Wagenmarkers, A.J.M.; Beckers, E.J.; Halliday, D.; Leiper, J.B.; Brouns, F.; Maughgam, R.I.; Westertrap, K.R. \& Saris, W.H.M. 1992. Gastric emptying, absorption and carbohydrate oxidation during prolonged exercise. J. Appl. Plys., 72:468-474.

Samuelson, G.; Bratteby, L.E.; Berggren, K.; Elverby, J.E. \& Kempe, B. 1996. Dietary iron intake and iron status in adolescent. Acta Paediatrica, 55(9):1033-1038.

Sevendran, R.R. 1984. The Plant Cell Wall as a Source of dietary fiber-Chemistry and structure. Am. Jour. of Clinical Nutrition. 39(2):320-337.

Täckholm,V. 1974. Students' Flora of Egypt (ed. 2). Cairo Univ. Press.

Wiebe, H.H. \& Walter, H. .1972. Mineral ion composition of halophytic species from Northern Utah. Amer. Middle Nature 87:241-245.

Yagodin, B.A. 1982. Agriculture Chemistry (ed. 1). Mir.Publisher, Moscow. 